\title{
Fast myosin heavy chain isoforms in horse skeletal muscle: an immunohistochemical and electrophoretic study
}

\author{
J. L. L. Rivero \\ Anatomy and Embryology Unit, Department of Comparative Anatomy and Pathological Anatomy, Faculty of Veterinary Science, \\ University of Cordoba, Spain
}

\begin{abstract}
Summary
The aim of this study was to characterize the fast myosin heavy chain (MyHC) isoforms present in equine skeletal muscle. Muscle biopsies were removed from the superficial region of the gluteus medius muscle of 5 mature horses, and analyzed by immunohistochemistry (using a number of monoclonal antibodies specific for rat MyHC isoforms) and sodium dodecyl sulfate-polyacrylamide gel electrophoresis. Immunohistochemistry allowed subdivision of two different muscle fibre populations containing a single fast MyHC, as well as one hybrid population, containing both fast $\mathrm{MyHC}$ isoforms. Electrophoresis of fast $\mathrm{MyHC}$ confirmed the existence of two resolvable bands, with an electrophoretic mobility parallel to type Ila and IIx rat MyHCs. The identity of one of these fast MyHCs was easily comparable with type Ila-MyHCs from rat skeletal muscle. However, a precise identification of the second fast MyHC was not made.
\end{abstract}

Keywords: $\quad$ muscle fibres, myosin, immunohistochemistry, electrophoresis, horse

Isoformen schwerer, schneller Myosinketten des Skelettmuskels von Pferden: eine immunhistochemische und elektrophoretische Studie

Ziel dieser Arbeit war die Charakterisierung der Isoformen schwerer, schneller Myosinketten des equinen Skelettmuskels. Zu diesem Zweck wurden bei 5 adulten Pferden Muskelbiopsien aus den oberflächlichen Schichten des Musculus glutaeus medius entnommen und immunhistochemisch analysiert. Der Autor verwendete dazu mehrere monoklonale Antikörper mit Spezifität zu den schweren Myosinketten der Ratte. Eine Natrium-Dodecylsulphat-Polyamidgel-Elektrophorese ermöglichte die Trennung der einzelnen Isoformen.

Myosin ist das dominierende Protein im Skelettmuskel. Es macht den Hauptteil der kontraktilen Elemente der Muskelfaser aus und besteht aus vier leichten und zwei schweren Polypeptidketten. Bis jetzt wurden 9 Isoformen der schweren Myosinketten im Skelettmuskel verschiedener Tiere entdeckt. Drei Haupt-Isoformen bestimmen die Eigenschaften des Muskels : die langsame B- oder Typ I-Kette und die zwei schnellen Myosinketten Ila und Ilb. Die unterschiedliche Verteilung dieser schweren Myosinketten bestimmt die drei Hauptfasertypen. Hinzu kommen noch Hybridtypen, welche die sogenannten Typ C-Fasern und Typ Ilab-Fasern bilden.

Durch Immunhistochemie konnten zwei Muskelfasertypen differenziert werden die je eine einzelne schwere Myosinkette hatten. Der Autor fand weiterhin eine Hybridform, welche beide Isoformen der schweren Myosinketten besaß.

Die elektrophoretische Auftrennung der schweren, schnellen Myosinketten ergab insgesamt zwei lösliche Banden, die eine elektrophoretische Mobilität zeigten, welche mit den Muskelfasertypen Ila und IIx der Ratte konform ging. Die Identität der Isoformen erwies sich als dieselbe des Typ lla-Myosins des Skelettmuskels der Ratte. Die zweite Isoform der schweren Myosinkette konnte allerdings nicht präzise identifiziert werden

Schlüsselwörter: Muskelfaser, Myosin, Immunhistochemie, Elektrophorese, Pferd

\section{Introduction}

Myosin is the predominant protein in skeletal muscle and it makes up the largest portion of the contractile apparatus of muscle fibres. This protein consists of four light chains and two heavy chains. To date, a total of nine distinct $\mathrm{MyHC}$ isoforms have been identified in adult skeletal muscles of a number of species (for reviews see Ref. Pette and Staron, 1990). Of these, three $\mathrm{MyHCs}$ exist in many species: the $\beta$-, slow- or type 1$\mathrm{MyHC}$ and the two fast (Ila and Ilb) MyHCs. The differential distribution of these $\mathrm{MyHCs}$ defines three main fibre types containing a single $\mathrm{MyHC}$ isoform (types I, IIA and IIB) and a number of hybrid fibre populations containing both I- and Ila-MyHCs (type 'C' fibres), and Ila- and IIb-MyHCs (type IIAB fibres). An additional fast $\mathrm{MyHC}$ isoform, termed IIx or IId, has been identified in muscles of rat, mouse, guinea pig and rabbit (Bär and Pette, 1988; Schiaffino et al., 1989) by using monoclonal antibodies and gel electrophoretic techniques. In humans the $\mathrm{MyHC}$ isoform found in IIB fibres is equivalent to rat IIx MyHC, not to rat Ilb MyHC (Smerdu et al., 1994). Several observations have suggested that differences in MyHC content contributes significantly for the differences in both maximum shortening ve- 


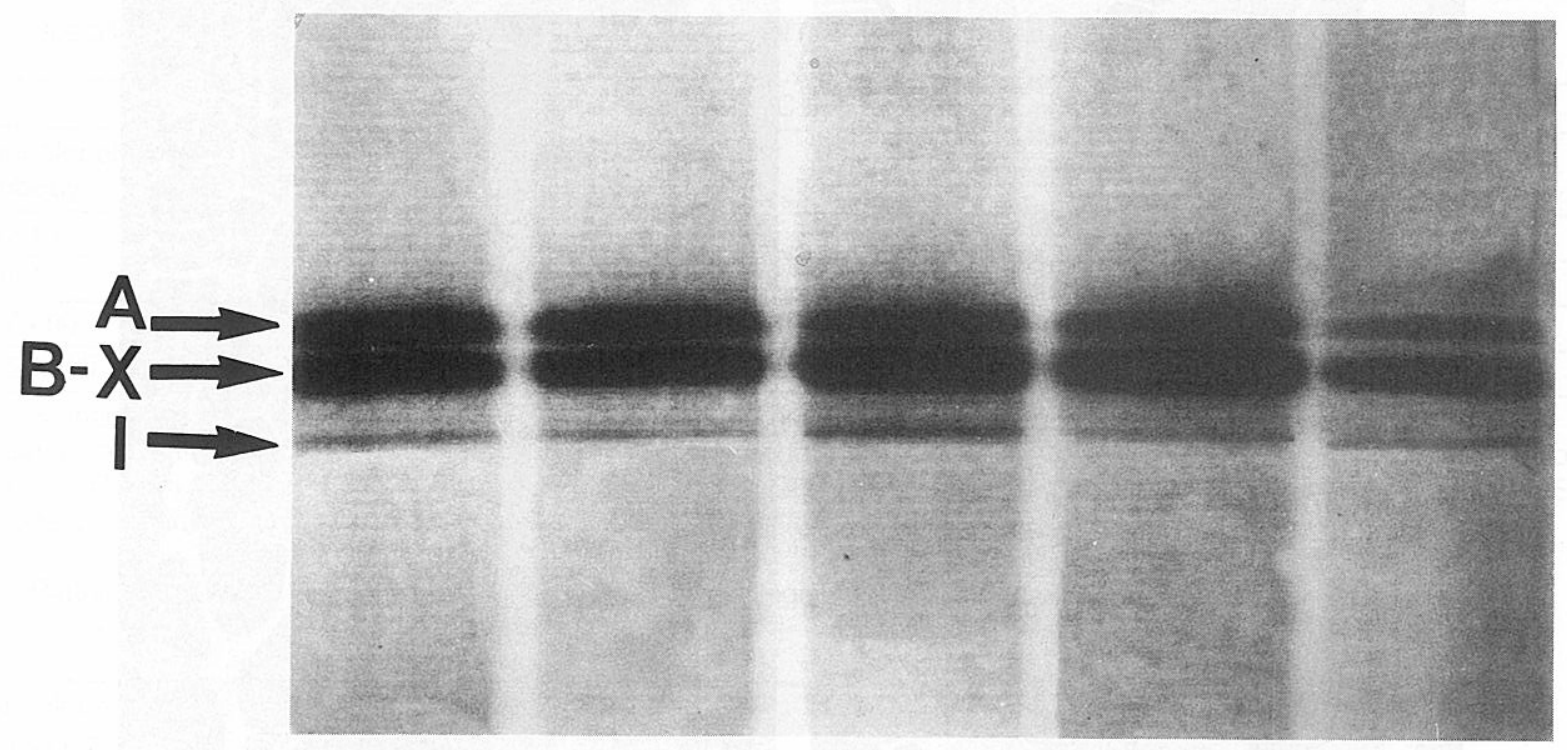

Fig. 2: $\quad 8 \%$ Sodium dodecyl sulfate-polyacrylamide gel electrophoresis (SDS-PAGE) gel of normal horse gluteus medius muscle of 5 horses (lanes 1 to 5) myosin heavy chains (MyHCs). This gel shows the separation profile of the three MyHCs in adult horse muscle. The isoforms are identified as types I (I), Ila (A) and IIb or IIX (B-X).

letal muscle, in order of mobility I>Ilb or IIx>lla. Type I MyHC was the fastest-migrating band (lower band), and type Ila MyHC was the slowest-migrating band (upper band). The second fast MyHC migrated to approximately the same level as $\| x-M y H C$ of rat muscle (Talmadge and Roy, 1993).

\section{Discussion}

Three different $\mathrm{MyHC}$ isoforms in horse skeletal muscle were identified using immunohistochemical and electrophoretic techniques: one slow and two fast isoforms. Using multiple MAbs against $\mathrm{MyHC}$ isoforms, immunohistochemistry allowed subdivision of the fast fibres in equine skeletal muscle into two different types. No previous immunohistochemical studies have reported two different fast MyHC isoforms in equine skeletal muscle (see Snow and Valberg, 1994 for a review).

In the present study, the electrophoretic method resulted in a consistent differentation of two type II horse MyHC isoforms (Fig. 2). As the slowest-migrating $\mathrm{MyHC}$ band comigrated with rat Ila $\mathrm{MyHC}$, on the basis of this analysis, it seems clear that type lla $\mathrm{MyHC}$ isoforms exist in the equine gluteus medius. By contrast, the identity of the second fast-MyHC (middle band in Fig. 2) was difficult to determine. Because its electrophoretic mobility was closer to type IIx- than type IIb-MyHC in rat muscles, a possible explanation could be that this equine $\mathrm{MyHC}$ is a type $\mathrm{llb} \mathrm{MyHC}$, but with a higher molecular weight than rat type IIb-MyHC. Another plausible explanation might be that this equine $\mathrm{MyHC}$ could be more closely related to rat type $\| x-M y H C$ rather than a type $\mathrm{Ilb}-\mathrm{MyHC}$. There is sufficient evidence to conclude that type IIx$\mathrm{MyHC}$ is coded by a distinct mRNA than type $\mathrm{llb}-\mathrm{MyHC}$, and that its primary distribution lies within a specific fibre population termed type IIX with distinct metabolic and contractile properties. Two human skeletal MyHC genes have been identified for fast Ila and IIx MyHCs based on pattern of expression and sequence homology with corresponding rat genes (Smerdu et al., 1994). The distribution of these Ila and IIx MyHC transcripts de- fines two major fast muscle fibre types expressing a single MyHC mRNA, i.e. either Ila or IIx MyHC RNA. Fibre typing by ATPase histochemistry showed that Ila MyHC transcripts are more abundant in histochemical type IIA fibres, whereas IIx MyHC transcripts are more abundant in type IIB fibres (Smerdu et al., 1994). This observation strongly suggests that the so-called human IIB fibres actually express a $\mathrm{MyHC}$ isoform equivalent to the rat $\mathrm{Ix} \mathrm{MyHC}$ isoform, and not the rat IIB isoform, and would therefore be more accurately classified as IIX fibres. Further studies are required to confirm if a similar situation occurs with those equine muscle fibres which contain a fast $\mathrm{MyHC}$ isoform other than Ila $\mathrm{MyHC}$ isoform.

The present results also indicate that, even under normal conditions, different $\mathrm{MyHCs}$ can coexist in single equine muscle fibres. The rarely occurring muscle fibre type containing both fast and slow myosin heavy chain substantiates the results reported by Snow et al. (1981) and Sinha et al. (1992). These fibres correspond to the type IIC muscle fibre identified histochemically, a muscle fibre type abundant in newborn foals, but extremely scarce in mature horses (Snow and Valberg, 1994). Also, a high percentage of fibres co-expressed both fast MyHCs, even in inactive animals.

In conclusion, results from the present study clearly show the existence of two fast $\mathrm{MyHC}$ isoforms in adult equine skeletal muscle. The differential distribution of these MyHCs defines two major fibre types containing a single MyHC (IIA and IIB or IIX) and one intermediate hybrid fibre population containing both fast MyHCs (type $\| A B$ or IIAX fibres). Whereas the identity of one of these two fast $\mathrm{MyHC}$ isoforms seems to be clearly a type Ila$\mathrm{MyHC}$ isoform, the present results are not conclusive regarding the second fast MyHC isoform.

\section{Acknowledgements}

This study was completed while José-Luis L. Rivero was working at the Department of Physiological Sciences, University of Califor- 
nia at Los Angeles, USA, supported by scholarships from the Spanish D.G.C.Y.T. (Ref: PR94-202) and the University of Cordoba, Spain.

\section{References}

Bär, A. and Pette, D. (1988): Three fast myosin heavy chain in adult rat skeletal muscle. FEBS Lett. 235:153-155.

Billeter, R., Lador, J., Howald, H. and Straub, R. (1987): Gel electrophoresis of proteins from single equine muscle fibres. In: Equine Exercise Physiology 2. J. R. Gillespie and N. E. Robinson, eds. ICEEP Publications, Davis, California. pp. 359-366.

Cobb, M. A., Schutt. M. A. Jr. and Hermanson, J. W. (1994): Morphological, histochemical, and myosin isoform analysis of the diaphragm of adult horses, Equus caballus. Anat. Rec. 238: 317-325.

Dubowitz, B. (1985): Muscle biopsy: A practical approach. 2nd edn. Bailliere Tindall, London. pp. 45-53.

Ecob-Prince, M., Hill, M. and Brown, W. (1989): Immunocytochemical demonstration of myosin heavy chain expression in human muscle. J. Neurol. Sci. 91: 71-78.

Hermanson, J. W., Hegemann-Monachelli, M. T. Daood, M. J. and LaFramboise, W. A. (1991): Correlation of myosin isoforms with anatomical divisions in equine biceps brachii. Acta Anat. (Basel), 141: 369-376.

Hughes, S. M., Cho, M. Karsh-Mizrachi, I., Travis, M., Silbersteins, L., Leinwand, L. A. and Blau, H. M. (1993): Three slow myosin heavy chains sequentially expressed in developing mammalian skeletal muscle. Devel. Biol. 158: 183-199.

Lindholm, A. and Piehl, K. I (1974): Fibre composition, enzyme activity and concentration of metabolites and electrolytes in muscles of Standardbred horses. Acta Vet. Scand. 15: 287-309.

Pette, C. and Staron, S. (1990): Cellular and molecular diversities of mammalian skeletal muscle fibres. Rev. Physiol. Biochem. Pharmacol. 116: 1-76.

Schiaffino, S., Gorza, L., Sartore, S., Saggin, L., Ausoni, S., Vianello, M., Gundersen, K. and Lmo, T. (1989): Three myosin heavy chain isoforms in type 2 skeletal muscle fibres. J. Muscle Res. Cell. Motil.
10: $197-205$

Sinha, A. K., Rose, R. J., Pozgaj, I. and Hoh, J. F. Y. (1992): Indirect myosin immunocytochemistry for the identification of fibres types in equine skeletal muscle. Res. Vet. Sci. 53: 25-31.

Smerdu, V., Karsh-Mizrachi, I., Campione, M., Leinwand, L. and Schiaffino, S. (1994): Type IIx myosin heavy chain transcripts are expressed in type Ilb fibres of human skeletal muscle. Am. J. Physiol. 267 (Cell Physiol. 36): C1723-C1728.

Snow, D. H. and Valberg, S. J. (1994): Muscle anatomy, physiology and adaptations to exercise and training. In: The athletic horse. $D$. R. Hodgson and R. J. Rose. WB Saunders, Philadelphia. pp. 145-179.

Snow, D. H., Billeter, R. and Jenny E. (1981): Myosin types in equine skeletal muscle. Res. Vet. Sci. 30: 381-382.

Sosnicki, A. A., Lutz, G. J., Rome, L. C. and Goble, D. O. (1989): Histochemical and molecular determination of fibre types in chemically skinned single equine skeletal muscle fibres. J. Histochem. Cytochem. 37: 1731-1738.

Talmadge, R. J., and Roy, R. R. (1993): Electrophoretic separation of rat skeletal muscle myosin heavy-chain isoforms. J. Appl. Physiol. 75: 2337-2340.

Thomason, D. B., Baldwin, K. M. and Herrick, R. E. (1986): Myosin isozyme distribution in rodent hindlimb skeletal muscle. J. Appl. Physiol. 60: 1923-1931.

Yamaguchi, M., Winnard, A., Takehana, K., Muguruma, M., Yamano, S., Aiping, L., Masty, J., Oba, T., Hunter, M., Yoshikawa, H. and Yoshikawa, T. (1993): Molecular analysis of horse skeletal muscle myosin. Bull. Equine Res. Inst. 30: 15-25.

Dr. José Luis López Rivero

Departamento de Anatomía

Facultad de Veterinaria

Universidad de Córdoba

Medina Azahara 9, 14005 Córdoba, Spain

FAX: (34) 572186 66; Phone (34) 57218675

E-mail: an1/orij@ucano.uco.es 